\title{
Bioremediation to Treat the World's Worst Ever Recorded Oil Contamination Case
}

\author{
Abdalrahman Alsulaili, Wasan Alkhamees, Saada Alghurbah, Aisha Almershed, Shahad Alrashdan \\ Department of Civil Engineering, Kuwait University \\ P.O.Box 5969, Safat 13060, Kuwait City, Kuwait \\ a.alsulaili@ku.edu.kw; wasan.alkhamees@gmail.com; saada.alghurbah@gmail.com; aisha.almershed@hotmail.com; \\ shahaadd@outlook.com
}

\begin{abstract}
The soil pollution issue in Kuwait was a result of the burning of the oil wells during the 1990 Gulf War. The contaminated soil's consequences have become more dangerous in many aspects, such as groundwater, dust action, human and animal's health. In this research, a bio-remediating technology known as the vermi-remediation was chosen to treat the oil contaminated soil by using of earthworms. The objective of this project is to conduct a series of experiments to conclude whether this technique is effective in treating Kuwait's soil and to what extent. The treatment results were found to surpass the results of the currently being implemented methods by both contamination percentage drops and time of treatment. The system was found to treat up to $62 \%$ in the TPH level for highly oilcontaminated soil samples, $55 \%$ for medium oil-contaminated soil samples and $71 \%$ for low oil-contaminated soil samples within three weeks.
\end{abstract}

Keywords: Environment, Pollution, Soil, Bioremediation.

\section{Introduction}

Soil contamination is portion of environmental degradation and is happened by the presence of man-made chemicals or the occurrence of changes around the natural soil environment. Contaminated soil possesses numerous effects that impact everything from water, air, vegetation and even human health as well [1]. Contamination is typically happened by manufacturing activity, improper waste disposal or agricultural chemicals.

As soon as oil is expelled into the environment, it undergoes weathering and a widespread of chemical, physical, and biological processes happen to this oil [2]. A huge quantity of oil sludge is produced during the processing and production of oil, contributing towards pollution to the environment. [3], stated that the oil sludge that is usually occur in production facilities and oil processing contains different concentrations of mineral particles $(5 \%-40 \%)$, waste oil $(40 \%-60 \%)$ and waste water $(30 \%-90 \%)$. Another form of rare oil spillage could occur during war, as a result of war crimes, similar to the ones that took place during the Gulf War in 1991 when the Iraqi forces deliberately set fire to hundreds of oil wells as an act of final vengeance, completely neglecting the potential effects of that on the environment.

[4] showed that petroleum contaminated soil can be harmful to the health of animals and people, affecting the lungs, liver, kidney and nervous system. Potentially affecting the immune and reproduction system and causing cancer. Benzene is considered one of the ingredients of hydrocarbons that has a human carcinogen [5]. Additionally, the infiltration of water into a soil can be reduced by oil spills, the nutrient mobility [6] and the ability of travelling through cell membranes with comfort into plants [7]. Thus, plant growth can be delayed in contaminated soil. [8]. Total petroleum hydrocarbon (TPH) can also cause a layer to be formed around seeds that blocks the movement of oxygen and water, which results in a slower rate of germination [7].

The 'soil remediation' can be known as the efforts which aim to decrease or exterminate the risks joined to the contaminated soil. In-situ and ex-situ remediation technologies able to remediate petroleum-contaminated soils can be categorized depending on their treatment mechanism: chemical, physical, electrical, biological and thermal [9].

Physical processes can be utilized to separate contaminated from uncontaminated materials or soil as concentrate through the utilize of physical variations between the contaminants and soil and to treat organic and inorganic contaminants (e.g. behavior in electric field and volatility) or between their physical properties (e.g. density and particle size) and the properties of soil [10]. 
Biological treatments are usable with contaminated soil and have major field for combination with other remediation processes [10]. Biological remediation is carried out at low expenses compared to the other substitutional techniques [11], though a large difference occurs in subjects of the treatment time, performance and environmental consequences of these mechanisms [12]. In Canada, Federal Contaminated [13] stated that bioremediation in 2005-2006 covered the most considerable part (74\%) of the innovative activity, as seen in Fig. 1.

Kalevitch [14] discussed the effect of the mission and structure of the soil food web on the ecosystem health. The results showed that the decreased bacterial or fungal activity and ruptured soil processes along with other factors, could perform to indicate a problem long before human health problems happen or the natural vegetation was lost. The problem of soil erosion could be solved by using fabricated soils.

Kumar [15] studied the In-situ bioremediation of groundwater for cleaning groundwater at its site. Metaheuristic hybrid algorithm had been utilized in this research to achieve Paretos for in-situ bioremediation of groundwater. Moreover, the efficiency of Paretos achieved with different population size had been assessed. The results show that large or small population size does not give well-spaced Paretos. For groundwater remediation, only the population size in a particular domain shows better efficiency. The analysis of cost of in-situ bioremediation shows that as the clean-up standard of groundwater increases, the percentage increase in cost increases.

However, the subject matter of this research focuses on the contamination of soils with various levels of hydrocarbons that were a result of the different means of oil pollution. In order to treat the contaminated soil, it was required to perform extensive research on every aspect of this huge issue, from oil types to remediation technologies. Information and required knowledge was collected from the numerous past researches which were performed by the parties responsible on the subject matter such as Kuwait Oil Company, Kuwait National Focal Point, and Kuwait Institute for Scientific Research.

\subsection{Case study}

Upon the Iraqi army's evacuation during the 1990 Gulf War, 613 oil wells were ignited in Kuwait, causing the largest environmental and ecological disaster in its history [16]. These were extinguished using approximately 12 billion gallons of salty water taken from the Arabian Gulf. Oil contaminated vast areas of soil in Kuwait; in fact, an estimated total area of contaminated land was reported to be approximately $114 \mathrm{~km} 2$. The total volume of contaminated soil was estimated at 26 million $\mathrm{m} 3$ [17]. These actions caused serious concern over possible long term catastrophic environmental consequences within and outside the Gulf region. Greater Burgan and Al-Rawdatain are the two essential areas drastically damaged by crude-oil pollution. These areas cover around 56,245 ha and 22,000 ha respectively [18].

The following features were developed [19]:

1.Oil-filled trenches - These are man-made trenches dug and filled with oil. 14 trenches were dug and filled by oil through pipelines.

2.Coastal oil deposits - These are also man-made trenches that are found along the coastline and filled with oil.

3.Wet and dry oil lakes, contaminated piles, and wellhead pits - Oil lakes are the most common contaminated features and are divided into two groups; wet and dry oil lakes. Both of these lakes are comprised of two layers, where the first upper layer in both kinds of lakes contains a higher level of Total Petroleum Hydrocarbon (TPH) whereas the second layer typically contains the lower level of Total Petroleum Hydrocarbon (TPH). The main difference between them is in the property of moisture content where the wet oil lakes' first layer contains a high level of water giving it a sludgy characteristic which is not found in the dry oil lakes. In Kuwait, the dry oil lakes are more dominant than the wet oil lakes due to Kuwait's extremely high average temperatures.

4.Contaminated piles are soil piles that were made during the early recovery stage of the war environmental crisis. They were the result of the process of stopping the spreading of oil flows caused by the destruction of the oil wells and to clear areas of heavy oil contamination as necessary to facilitate fire-fighting or other KOC field operations.

5. Tarcrete - Tarcrete is a consolidated material which resembles an asphalt layer. This is due to air borne contamination from the crude oil well fires that assembled and settled out in desert landscape regions. The tarcrete makeup a crust of different thickness through big regions of the desert.

It can be concluded that in general, the contaminated land in Kuwait is composed of three overall layers. The first layer is sludge or 'skin'- separate layer. While the second layer is sand impacted with oil that has various TPH concentrations. Usually, this layer is treatable to limit intervention. Finally, the bottom layer is visually clean sand layer. 


\subsection{Specialization of Kuwait's oil contaminated soil}

Kuwait's contaminated soil was characterized to be very dissimilar to common oil contaminated soils; which initiated many problems during the characterization and treatment phases.

To begin with the way in which these lakes were formed has never occurred before. The way in which the land was polluted was forceful as it was a result of a war crime. This further developed the problem of having an unrealistic area of contaminated land that at first thought may have seemed impossible to treat. The total area of the oil contaminated lands broke the record in terms of the biggest oil polluted area in history, which has caused it to earn its place amongst the top ten worst environmental crises to ever occur.

The extinguishment of these wells was done using 12 billion gallons of Arabian Gulf water, which contains a high salinity concentration of 35,000 mg/l [20]. This resulted in a rare petroleum-salt- and other chemicals mixture.

Furthermore, soil contaminated lands in Kuwait have been around for over 20 years and are therefore considered to be extremely weathered. This lead them to develop irreversible properties such as toughness which makes them difficult to treat using conventional methods.

1.3 Reasons for soil remediation

In Kuwait, the remediation of the oil contaminated soil is critical and essential to the safety, health, environment, and general development of the country.

The remediation of oil contaminated soils in the northern region is necessary to protect Kuwait's only fresh groundwater resources. Hydrocarbon pollution expanded to the aquifers in north Kuwait, which are estimated as vital reserves for fresh ground water, especially for urgently cases.

Residential areas and areas in which there is a high human activity must be completely free of any polluted soil to protect humans from the potential health hazards. It is therefore cardinal to treat all lakes within $1 \mathrm{~km}$ of these areas.

Moreover, the wind in Kuwait has the potential to carry some of the contaminated soil in Kuwait in the form of dust. This dust contains hazardous chemicals (most commonly benzo(a)pyrene) which if exposed at high levels will cause health threats to humans [21].

While the volume of contamination in the Greater Burgan oil field (South) is the greatest, treatment of its contamination is less urgent than the northern oil fields. Within Burgan, all lake beds, especially the ones near Ahmadi and in the working areas such as gathering centers in the oilfield, are considered to be a threat to human health and harmful to all types of life, including native flora and fauna. These lakes should be given the highest priority. The remediation of lake beds near roads and wells and pipelines is also necessary for operation and maintenance work, but is of second priority.

1.4 Remedial technology investigation in Kuwait

The following section explains the remediation methods that have been subjected to bench-scale testing by the Kuwait Oil Company (KOC) in the context of the types of contamination in Kuwait [22-23]. These methods are approved by the Kuwaiti Environmental Protection Agency (KEPA).

Bioremediation - Bioremediation techniques are pointed across encouraging microorganisms to arise and utilize impurities as an energy and food source by making a suitable environment for these microorganisms. In Kuwait, the soils contaminated with 'low end' TPH concentrations (less than 5\%) have been addressed with enhanced active bioremediation carried out using a chemical referred to as "Oilzapper". Five several bacterial strains that are inactive and combined with a transporter material such as grinded corncob. Oilzapper is the combination of five bacteria. Oilzapper feeds on hydrocarbon compounds appear in the hazardous hydrocarbon waste produced by oil refineries, known as Oil Sludge and switches them into innocuous water and $\mathrm{CO} 2$ in an aerobic reaction. The Oilzapper was carefully filled into sterile polythene bags and tight aseptically for secure transfer to Kuwait. The product has a shelf life of three months at circulating temperature. The technique was utilized strongly and low-contaminated soils in Kuwait were treated in a surprisingly fast rate. This unexpected speed of bioremediation was later found out to be a result of additional phytoremediation. The high abundance and almost daily exposure of sunshine in Kuwait catalyzed the remediation procedure and allowed the biodegradation to finish surprisingly fast.

Soil Washing - Soil washing is a water-based technique used to clean soil either by suspension or dissolution of contaminants. The process starts off by the removal of large particles such as rocks from the soil sample, after which the remaining material crosses the soil scrubbing unit in which the soil is combined with a washing solution and additive chemicals if needed which help breakdown soil particles and separate contaminants from the soil. The soil is separated into coarse and fine grains. The coarse grains settled out from the processed soil is then examined for contaminants, if clean the material can then be utilized, if not, the material can be run through the soil washer again which may result in finer soil 
particles or may be proceeded to alternative remediation methods. The fine grains usually contain larger amounts of contaminants than coarse grains since contaminants are prone to bind to fine grained soils thus chemical additives are during the treatment of fine particles.

Thermal Desorption - Thermal desorption is a type of physical remediation, where heat is subjected to the soil to evaporate organic contaminants from soil and other solid matrices. This kind of remediation technology is used to treat soil with a relatively level of contamination of Total Petroleum Hydrocarbon (TPH) levels ranging from 10-15\%.

\section{Methodology}

\subsection{Comparison and selections of methods}

The first part of the methodology of this research was to study the different available remediation technologies in order to choose one that is most suitable for the treatment of Kuwait's special soil contamination case. This section studies and

grades the three previously explained remediation technologies based on the above preliminary literature review and a set of metrics according to Ejbarah [24]. The House of Quality is the engineering decision tool that was used to compare the best remediation alternative methods based on a set of requirements. Objective Trees, Pairwise Comparison Charts, and Weighted Objectives Trees were developed to assess the use of House of Quality technique. The final decision was based on the total weighted score for each method.

The developed weighted decision tree is shown in Figure 1. The scores for each of the previously mentioned factors can be shown in Table 1.

Based on these scores, the bioremediation technique is the one that complies with Kuwait's situation. This project aimed to improve the weaknesses of the already existing bioremediation method in Kuwait. After excessive research, a study that proves the ability of a certain kind of earthworms (Eisenia Fetida) to breakdown heavy metal resulting from dump waste and polluted backwaters was found. This method is known as vermi-remediation and was implemented in this project to try and treat Kuwait's weathered oil contaminated soil. 


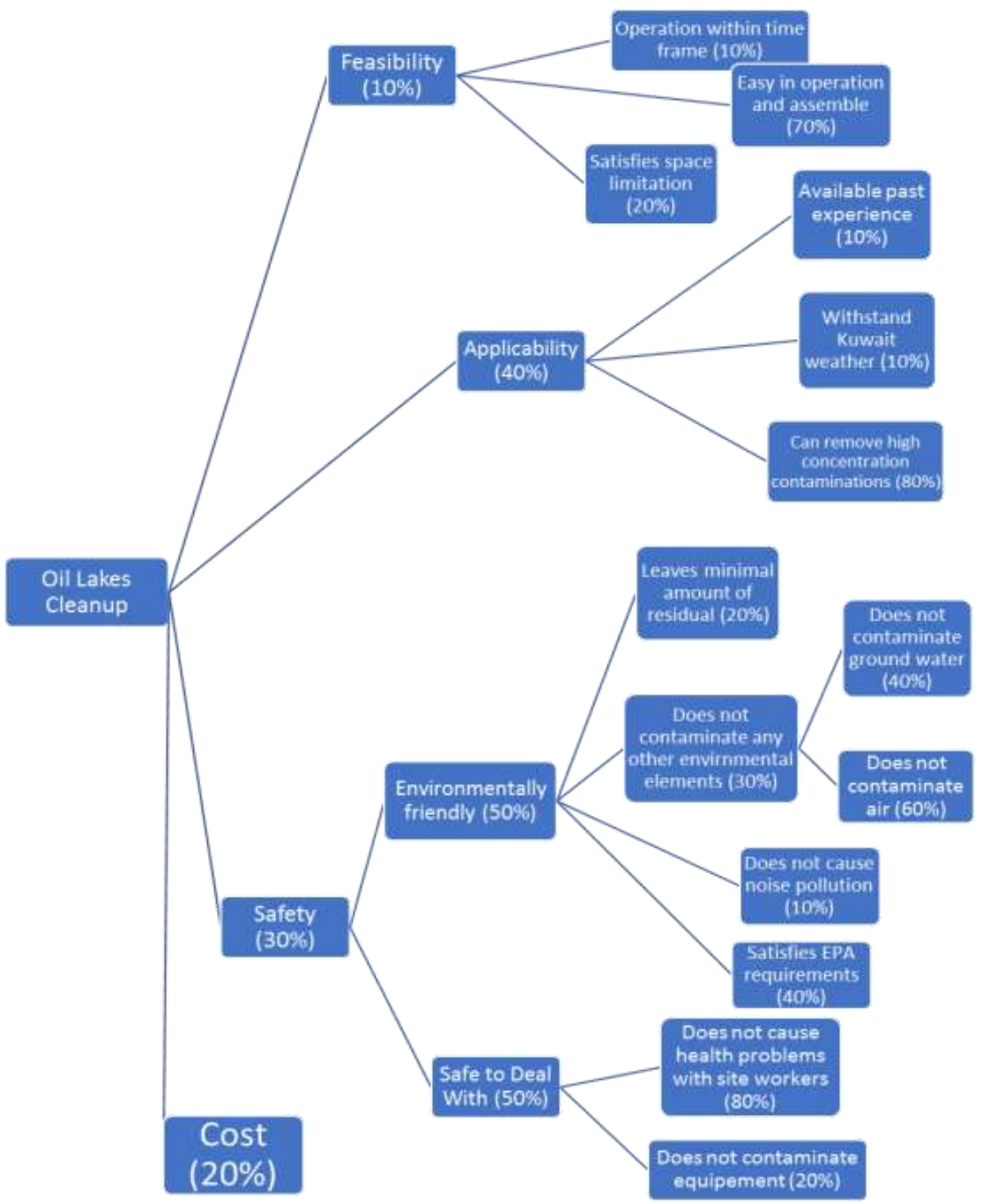

Fig. 1: Weighted decision tree [24].

Table 1: Comparisons and scores. 


\begin{tabular}{|c|c|c|c|c|}
\hline PARAMETERS & & $\begin{array}{l}\text { METHOD } \\
\text { Bioremediation }\end{array}$ & Washing & Thermal \\
\hline \multirow[t]{4}{*}{$\begin{array}{l}\text { Feasibility } \\
(10 \%)\end{array}$} & $\begin{array}{l}\text { Operation within time frame } \\
(10 \%)\end{array}$ & 2 & 10 & 10 \\
\hline & $\begin{array}{l}\text { Easy in operation and assembly } \\
(70 \%)\end{array}$ & 56 & 28 & 28 \\
\hline & Satisfies space limitation (20\%) & 10 & 18 & 18 \\
\hline & FEASIBILITY SCORE (10\%) & 6.8 & 5.6 & 5.6 \\
\hline \multirow[t]{4}{*}{$\begin{array}{l}\text { Applicability } \\
(40 \%)\end{array}$} & $\begin{array}{l}\text { Available past experience } \\
(10 \%)\end{array}$ & 7 & 4 & 4 \\
\hline & $\begin{array}{l}\text { Withstands Kuwait weather } \\
(10 \%)\end{array}$ & 4 & 9 & 9 \\
\hline & $\begin{array}{l}\text { Can remove high contamination } \\
\text { concentrations }(80 \%)\end{array}$ & 40 & 64 & 72 \\
\hline & $\begin{array}{l}\text { APPLICABLILITY } \\
(40 \%)\end{array}$ & 20.4 & 30.8 & 34 \\
\hline \multirow[t]{6}{*}{$\begin{array}{l}\text { Environmentally } \\
\text { Friendly }(15 \%)\end{array}$} & $\begin{array}{l}\text { Leaves minimal amount of } \\
\text { residual }(20 \%)\end{array}$ & 20 & 12 & 10 \\
\hline & $\begin{array}{ccc}\text { Does not } & \text { contaminate } \\
\text { groundwater }(15 \%)\end{array}$ & 15 & 15 & 15 \\
\hline & Does not contaminate air $(15 \%)$ & 15 & 10.5 & 10.5 \\
\hline & $(10 \%){ }^{\text {Does not cause noise pollution }}$ & 9 & 3 & 3 \\
\hline & $\begin{array}{l}\text { Satisfies EPA requirements } \\
(40 \%)\end{array}$ & 40 & 24 & 24 \\
\hline & $\begin{array}{l}\text { ENVIRONMENTALLY } \\
\text { FRIENDLY SCORE }(15 \%)\end{array}$ & 14.85 & 6.675 & 9.375 \\
\hline \multirow[t]{3}{*}{$\begin{array}{l}\text { Safe to deal } \\
\text { with }(15 \%)\end{array}$} & $\begin{array}{l}\text { Does not cause health problems } \\
\text { with site workers }(80 \%)\end{array}$ & 48 & 32 & 24 \\
\hline & $\begin{array}{c}\text { Does not contaminate } \\
\text { equipment }(20 \%)\end{array}$ & 18 & 12 & 10 \\
\hline & $\begin{array}{l}\text { SAFE TO DEAL WITH } \\
\text { SCORE }(15 \%)\end{array}$ & 9.9 & 6.6 & 5.1 \\
\hline \multirow[t]{2}{*}{ Cost $(20 \%)$} & General Cost $(100 \%)$ & 90 & 50 & 60 \\
\hline & COST SCORE (20\%) & 18 & 10 & 12 \\
\hline $\begin{array}{r}\text { TOTAL } \\
\text { SCORE }(100 \%)\end{array}$ & & 69.95 & 60.875 & 66.075 \\
\hline
\end{tabular}




\subsection{Vermi-remediation Advantages}

This section shows the advantages of using earthworms in the process of remediating oil-contaminated soil.

1. Earthworms host bacteria can biodegrade chemicals within their gut. Earthworms associations with bacteria can be achieved in any earthly soil system that worms inhabit [25]. Bacteria that move through the earthworm gut are simply eaten by the earthworm to gain nutrients [25]. $5 \mathrm{~kg}$ of earthworms (totalling around 10,000 individual earthworms) are typically able to degrade $1000 \mathrm{~kg}$ of waste within only 30 days, converting the waste into useful vermi-compost.

2. The efficiency of vermicomposting in degrading fuel oil in water emulsions from oil spills was measured by conducting an experiment involving three trays of known volumes and surface areas containing the vermicomposting samples. The density of earthworms used, Eisenia foetida earthworms, were $300 \mathrm{~g}$-earthworms $/ \mathrm{m} 2$. A temperature of $25^{\circ} \mathrm{C}$ was maintained throughout the experiment period, as well as maintaining a moisture content ranging between 60-80\%, for a 6 months period tiling the soil daily to assure aeration, kitchen food waste was added periodically to the reactor after full consumption of the food previously added where the amount of food shall just enough to encourage the worms to feed on the oil. Throughout the experiment, light was subjected on the reactors to avoid escape of worms and encourage burrow. This controlled environment allowed for the same conditions to be experienced by all the reactors. After short period, the asphaltens within the oil can be a source for microorganisms to obtain carbon and energy. The addition of factors, like potato peelings and cow bed, allowed the breaking down of complex compounds which was necessary for the further degradations with earthworms.

3. Earthworms are able to endure $0.5 \%$ crude oil and survive in this environment for 7 days. However, the survivals of worms were reduced to less than $40 \%$ when exposed to soil containing $1.5 \%$ oil. Verimremedition for soil with $1.2 \%$ crude oil was not harmful to survival of earthworms for 10 days. Also, earthworms degraded oil-contaminated soil containing $0.2 \%$ Total petroleum hydrocarbon (TPH) in worm's vermicast.

4. The impact of earthworm species on soil being remediated is a positive one. It was revealed that, whichever bioremediation system chosen, Polycyclic aromatic hydrocarbons (PAHs) disappeared noticeably faster in soils containing worms as compared to the bare soils.

5. The presence of Eisinia fetida had caused an increased microbial catabolic activity, which resulted in the loss of $91 \%$ (1074 mg / kg of soil to $96 \mathrm{mg} / \mathrm{kg}$ ) of crude oil contamination within treatment period of 56 days. Furthermore, the degradation of oil contaminated soil with three different earthworm species (Lumbricus terrestris, Eisenia fetida and Allolobophora chlorotica) for 28 days decreased the concentrations of TPH in samples 30-42\%, 31-37\% and 17-18\% respectively whereas the concentration of TPH in samples without earthworms was slightly decreased (9-17\%) compared to the initial concentration of TPH.

6. Only 5-10\% of the consumed material is absorbed into the body and the remaining is utilized in the form of fine mucus-coated granular aggregates called vermicastings which are wealthy in phosphates, nitrates, potassium, micronutrients, and beneficial microbes for the soil.

7. Earthworms promote soil aeration and fragmentation and bring about soil dispersion and turning.

\subsection{Vermi-remediation methodology}

This section explains the procedure that was followed to test vermi-remediation on Kuwait's soil.

1. Soil Sample Collection: Three samples with different levels of TPHs (low, medium, high) were collected from Burgan oil field. Soil samples of different TPH levels were obtained at a depth of approximately $40 \mathrm{~cm}$ below the ground level, each. The samples filled 4 plastic containers after extraction from the soil using a shovel.

2. Soil Sample Separation: Most of the collected soil samples were coarse samples that were found to have a very sludgy property and since vermi-remediation cannot be implemented on coarse particles, the soil had to be broken down into finer samples. This was done by first using the Los Angeles abrasion machine to crush the larger particles into smaller ones that were further separated using sieves to get the finest possible sample. There was a total of 4 reactors. These reactors have been constructed from a plastic container of length, width and height $0.6 \mathrm{~m}, 0.30 \mathrm{~m}$ and $0.25 \mathrm{~m}$, respectively. This gives each container a total surface area of $0.81 \mathrm{~m} 2.1 .5 \mathrm{~mm}$ ventilation and drainage holes on the base, lower edge, and lid of each container were drilled.

3. TPH measurement: The total petroleum hydrocarbon of the three collected samples were measured. It was found that the difference in TPH levels in the collected samples was not very effective, therefore four new samples were created by mixing different ratios of the collected samples as explained in the next step.

4. Samples preparation: The four newly made mixtures that will undergo the vermi-remediation treatment are as follows: 
i. Pure mixture - The three collected contaminated soil samples were mixed together in equal proportions (this sample possesses the highest TPH concentrations).

ii. 1:2.5 Sample - The pure mixture was mixed with clean sand in a ratio of 1:2.5 respectively (this sample possesses a medium TPH concentration).

iii. 1:5 Sample - The pure mixture was mixed with clean sand in a ratio of 1:5 respectively (this sample possesses the lowest TPH concentrations).

iv. Pure Clean Sand - This was used as a control to see whether or not the activity of the earthworms was affected by the oil contamination.

5. Testing Soil Properties: Prior to initiating the remediation experiment, the chemical and physical properties of the 4 prepared contaminated soil samples must be tested and recorded for future assessment.

6. Creating a suitably built prototype: Since the vermi-remediation treatment uses earthworms, the factors that affect the life and activity of earthworms must be highly taken into consideration to ensure the success of the experiment. Therefore, a suitable environment had to be sustained to achieve the best results. This was done by preparing four small reactors; one for each of the samples. Certain factors had to be maintained throughout the experiment period such as the temperature at $250 \mathrm{C}$, moisture content at $30-50 \%$, the constant availability of oxygen, light intensity, and a moderate amount of food to provide just enough energy for the earthworms to feed on the oil. Finally, the $\mathrm{pH}$ had to be sustained as neutral to run the test smoothly.

7. Compost and earthworms addition: Compost was added as well as two types of earthworms; Eisenia Fetida and African earthworms. At this point onwards, the soil treatment process begins.

The experiment was conducted for a testing period that lasted 3 weeks. The results were measured by testing the soil properties previously tested once again to note the changes that will prove either the success or failure of the experiment.

\section{Results}

The following tests were conducted, and their results were recorded in the Tables 2-7 below:

TPH (Total petroleum hydrocarbon) as hexane extractable material

The results of this test were found to be positive for all the samples with an inverse relationship between the initial TPH level and drop percentage. The biggest drop in TPH levels was found in the 1:5 sample as this had the lowest TPH concentration to begin with. Because of that, it was predicted that the 1:2.5 sample would have the second biggest drop due to it having the second lowest TPH concentration but that was not the case. The pure mixture sample surprisingly had the second biggest drop instead. This may be due to the fact that not all the samples were given equal amounts of food, water, and oxygen.

Table 2: TPH concentrations.

\begin{tabular}{crrr}
\hline Sample & $\begin{array}{c}\text { Initial } \\
\text { TPH }(\mathrm{mg} / \mathrm{Kg})\end{array}$ & $\begin{array}{r}\text { TPH at 3 } \\
\text { weeks }(\mathrm{mg} / \mathrm{Kg})\end{array}$ & $\begin{array}{c}\text { Removal } \\
\text { Efficiency }(\%)\end{array}$ \\
\hline $\begin{array}{c}\text { Pure } \\
\text { mixture }\end{array}$ & 36,690 & 21,340 & 62.41 \\
$1: 2.5$ & 8,870 & 5,470 & 55.69 \\
$1: 5$ & 7,460 & 2,800 & 71.31 \\
\hline \hline
\end{tabular}

\subsection{Total organic carbon analyses - (TOC)}

In our results, it was found that the TOC for the pure mixture decreased, whereas it increased for the 1:2.5 and 1:5. To begin with, in the pure mixture it was noted that the earthworms were not surviving greatly in a fully contaminated medium. This problem was solved through the division of the sample into two equal halves where one of the halves was made of compost only while the other half was made of the purely contaminated mixture. This was done as a way to ensure the survival of the earthworms by giving them a medium to live in (compost half) and allowing them to travel to the contaminated 
half for the food placed there. Therefore, the TOC was bound to decrease in the pure mixture since earthworms did not stay there. As for the other samples, the TOC naturally increased due to the presence of the earthworms in their mediums.

Table 3: Total organic carbon.

\begin{tabular}{|c|c|c|}
\hline Sample & $\begin{array}{ll}{ }_{(\mu g / g)} \text { Initial TOC } \\
\end{array}$ & $\underset{(\mu g / g)}{\text { TOC at } 3 \text { weeks }}$ \\
\hline Pure mixture & 59,746 & 55,403 \\
\hline $1: 2.5$ & 17,668 & 22,269 \\
\hline $1: 5$ & 14,534 & 20,857 \\
\hline
\end{tabular}

\subsection{Percentage moisture test}

Percentage Moisture Test: The moisture content was found to be higher than to begin with which meant that good care was taken in watering the samples throughout the trial and the environment was healthy and acceptable for the worms.

Table 4: Moisture content.

\begin{tabular}{lcccc}
\hline \multirow{2}{*}{ Sample } & \multicolumn{2}{c}{ Initial percentage } & \multicolumn{2}{c}{ Percentage at 3 weeks } \\
\cline { 2 - 5 } & $\%$ & $\%$ & $\%$ SOLID & $\%$ \\
& SOLID & MOIST & & MOIST \\
\hline Pure mixture & 98.51 & 1.49 & 76.43 & 23.57 \\
$1: 2.5$ & 97.49 & 2.51 & 90.17 & 9.83 \\
$1: 5$ & 98.96 & 1.04 & 87.79 & 12.21 \\
\hline
\end{tabular}

\section{3. $\mathrm{pH}$ concentration}

$\mathrm{pH}$ : The results showed a decrease in $\mathrm{pH}$ concentration after 3 weeks compared to the initial $\mathrm{pH}$ concentration in all mixtures. This test proved that the $\mathrm{pH}$ was successfully maintained at a neutral level which is the required condition in our experiment.

Table 5: Ph.

\begin{tabular}{cll}
\hline Sample & Initial pH & pH at 3 weeks \\
\hline $\begin{array}{c}\text { Pure } \\
\text { mixture }\end{array}$ & 8.03 & 7.09 \\
$1: 2.5$ & 8.17 & 7 \\
$1: 5$ & 8.21 & 6.95 \\
\hline
\end{tabular}

\subsection{Ortho-phosphate, nitrite/nitrate analysis}

Ortho-Phosphate, Nitrite/Nitrate Analysis: The concentrations of phosphate and nitrates/nitrites in the soil have increased due to the biological nature of the earthworms; this drastically improves the soil quality and makes it more fertile [26]. 
Table 6: Ortho-phosphate and nitrite/nitrate.

\begin{tabular}{|c|c|c|c|c|}
\hline \multirow{2}{*}{ Sample } & \multicolumn{2}{|c|}{ Ortho Phosphate ( $\mathrm{mg} / \mathrm{L})$} & \multicolumn{2}{|c|}{ Nitrite/Nitrate $(\mathrm{mg} / \mathrm{L})$} \\
\hline & Initial & weeks $^{3}$ & Initial & weeks $^{3}$ \\
\hline $\begin{array}{l}\text { Pure } \\
\text { mixture }\end{array}$ & 0.107 & 20.934 & 2.091 & 9.29 \\
\hline $1: 2.5$ & $<\mathrm{DL}^{*}$ & 9.482 & 6.56 & 42.919 \\
\hline $1: 5$ & 0.069 & 7.404 & 5.911 & 82.583 \\
\hline
\end{tabular}

\subsection{Metals - inductively coupled plasma atomic emission spectroscopy (ICP-EOS)}

Metals - Inductively coupled plasma atomic emission spectroscopy (ICP-EOS): The concentration of potassium increased after the remediation. This is a good indication since potassium is an important plant nutrient and is required in great quantities for reproduction of plants and suitable growth. This gives us more fertile soil that can be used to grow vegetation. Iron concentrations have also increased in the soil and this is a positive impact because an iron deficiency will cause chlorosis, which is a lack of chlorophyll in plants. Iron is also necessary for some enzyme functions in many plants. The chromium levels have increased in the soil. Chromium impacts on plant growth, seed germination, photosynthesis, and the uptake of a types of nutrients. As for the rest of the metals, there was no pattern of change throughout the weeks for each of the samples.

Table 7: Metals.

\begin{tabular}{|c|c|c|c|c|}
\hline Sample & & $\begin{array}{l}\text { Pure } \\
\text { re }\end{array}$ & $1: 2.5$ & $1: 5$ \\
\hline \multirow{2}{*}{ Aluminum (mg/kg) } & Initial & 4514.26 & 3614.19 & 5006.06 \\
\hline & 3 weeks & 6172.97 & 4047.91 & 3433.19 \\
\hline \multirow{2}{*}{ Barium (mg/kg) } & Initial & 79.18 & 23.58 & 28.29 \\
\hline & 3 weeks & 108.6 & 36.6 & 22.78 \\
\hline \multirow{2}{*}{ Calcium (mg/kg) } & Initial & 30311.64 & 17455.92 & 16056.99 \\
\hline & 3 weeks & 45322.52 & 15515.14 & 13976.53 \\
\hline \multirow{2}{*}{ Chromium (mg/kg) } & Initial & 20.3 & 9.23 & 9.09 \\
\hline & 3 weeks & 34.02 & 14.42 & 11.39 \\
\hline \multirow{2}{*}{ Iron $(\mathrm{mg} / \mathrm{kg})$} & Initial & 6097.86 & 3303.61 & 4585.69 \\
\hline & 3 weeks & 8062.28 & 4015.75 & 3436.61 \\
\hline \multirow{2}{*}{ Potassium (mg/kg) } & Initial & 726.83 & 438.7 & 621.46 \\
\hline & 3 weeks & 1354.18 & 923.81 & 850.89 \\
\hline $\begin{array}{l}\text { Magnesium } \\
(\mathrm{mg} / \mathrm{kg})\end{array}$ & Initial & 5795.35 & 2010.05 & 2928.46 \\
\hline
\end{tabular}




\begin{tabular}{|c|c|c|c|c|}
\hline \multirow{3}{*}{$\begin{array}{l}\text { Manganese } \\
(\mathrm{mg} / \mathrm{kg})\end{array}$} & 3 weeks & 5725.5 & 2740.38 & 2413.71 \\
\hline & Initial & 121.82 & 46.13 & 57.6 \\
\hline & 3 weeks & 163.55 & 58.78 & 52.4 \\
\hline \multirow{2}{*}{ Sodium (mg/kg) } & Initial & 1162.32 & 876.38 & 887.23 \\
\hline & 3 weeks & 1220.72 & 544.53 & 640.16 \\
\hline
\end{tabular}

\section{Conclusions}

Oil pollution of soil in Kuwait is an issue that has been around for several years. Due to the harmful environmental and health impacts of oil pollution, Kuwait is seeking and implementing new and multiple treatment methods to remediate the soil. Kuwait has found difficulty in treatment due to the unique conditions of Kuwait's soil that have never been found elsewhere.

Despite the availability of remediating methods in Kuwait, this research paper aims to pursue a modern and effective method in the field that serves the environment in specific.

To do that, the vermi-remediation method was carried out within a period of three weeks. This method was proven to be successful based on the many positive results. First and foremost, the main objective that was to lower the TPH levels was achieved on contaminated soil. Contrary to popular belief, this was accomplished at a rate surprisingly faster than predicted. What's more, despite the high salinity in Kuwait's polluted soil, it was found that this method was not affected negatively by this factor. In addition to the cleansing procedure, it was deduced that the treated soil contained high amounts of nutrient, indicating very fertile soil. Finally, vermi-remediation is an environmentally friendly method that is easy to implement and is very economically beneficial.

By all counts, and with these mentioned proven results, vermi-remediation is an undeniably successful remediation method. On the whole, more research should be done to help learn to functionally treat the different contaminated soils in Kuwait to ensure the safety and sustainability of Kuwait's future environment.

\section{Acknowledgements}

The Authors would like to acknowledge Kuwait Foundation for the Advancement of Science for their financial support, and the National Unit for Environment Research Services (NUERS) at Kuwait University for providing the tools and facilities to conduct the laboratory analyses.

\section{References}

[1] A. Kabata-Pendias, Trace elements in soils and plants. CRC press, 2010.

[2] G. Gitschlag, "Effects of the Mega Borg Oil on Sea Turtles along the Upper Texas Coast," The Mega Borg Oil Spill: Fate and Effects Studies, NOAA Damage Assessment Center, Rockville, MD, 1992.

[3] M. Francis and L. Stehmeyer, "Biotreatment of waste oil and sludges," in Gould, W.D. and Lord, S.Ž. (Eds.), Proceedings of the 8th Annual General Meeting of Biominet, MSL, Calgary, Alberta, 1991, pp. 55-74.

[4] D. G. Rushton, A. E. Ghaly and K. Martinell, "Assessment of Canadian regulations and remediation methods for diesel oil contaminated soils," American Journal of Applied Science, vol. 4, no.7, pp. 465-478, 2007.

[5] IARC, 'IARC Monographs on the evaluation of the carcinogenic risk of chemicals to humans', in Polynuclear Aromatic Compounds, Part 1: Chemical, Environmental and Experimental Data, International Agency for Research on Cancer, Lyon, France, pp. 33-91, 1983.

[6] J. L. Kirk, et al., "The effects of perennial ryegrass and alfalfa on microbial abundance and diversity in petroleum contaminated soil," Environmental Pollution, vol. 133, no. 3, pp. 455-465, 2005.

[7] G. Adam and H. Duncan, "Influence of diesel fuel on seed germination," Environmental Pollution, vol. 120, no. 2, pp. 363-370, 2002.

[8] E. Kaimi, T. Mukaidani, and M. Tamaki, "Screening of twelve plant species for phytoremediation of petroleum hydrocarbon-contaminated soil," Plant Production Science, vol. 10, no. 2, pp. 211-218, 2007.

[9] Riser-Roberts, E. Remediation of Petroleum Contaminated Soils: Biological, Physical, and Chemical Processes. CRC Press, Boca Raton, 1998. 
[10] C. P. Nathanail and R. P. Bardos, Reclamation of Contaminated Land, Wiley, U.S, 2004.

[11] D. Zhao, "Selection of functional consortium for crude oil-contaminated soil remediation," International Biodeterioration \& Biodegradation, vol. 65, no. 8, pp. 1244-1248, 2011.

[12] S. K. Banerji, "Bioremediation of soils contaminated with petroleum hydrocarbons using bioslurry rectors," U.S. Army Corps of Engineers, Miscellaneous Paper IRRP-95e2, Final Report, 1995.

[13] Federal Contaminated Sites. (2012). Action Plan Annual Report 2005-2006. [Online]. Available: http://publications.gc.ca/collections/collection_2009/ec/En1-43-2006E.pdf

[14] M. V. Kalevitch \& V. I. Kefeli, "Study of bacterial activity in fabricated soils," International journal of environment and pollution, vol. 29, no. 4, pp. 412-423, 2007.

[15] D. Kumar, S. Mathur, and B. K. Panigrahi, "Hybrid algorithm performance with varying population size for multiobjective optimisation of in-situ bioremediation of groundwater," International Journal of Bio-Inspired Computation, vol. 5, no. 3, pp. 164-174, 2013.

[16] A. Al-Yousifi, (2011) 'Kuwait invasion: The evidence, The retreat: oil fires' Kuwait Invasion [Online]. Available: http://www.evidence.org.kw/introduction.php?10

[17] M. Al-Mumin, 'Kuwait environmental remediation program' in NEW ORLEANS 2016: Paper presented at the 23rd International Petroleum Environmental Conference, New Orleans, LA, 2016.

[18] S. Omar, G. Grealish, and W. Roy, "Types and extent of soil contamination in greater Al-Burqan oil field, Kuwait," Kuwait Journal of Science and Engineering, vol. 33, no.2, pp. 89-99, 2006.

[19] A. Ali, "Study of characterization of oil contaminated soil in Kuwait Hera Ag Ambiental company soil remediation project Kuwait," IJISET - International Journal of Innovative Science, Engineering \& Technology, vol. 3, no. 3, pp 7$18,2016$.

[20] B. Bjerkeng and J. Molvær, "Water Exchange and Circulation of the Arabian Gulf - Preliminary Study of Suitability for Seawater Scrubber Discharges," Norwegian Institute for Water Research Research. Report LNR 4282-2000, Oslo.

[21] S. N. Al-Yakoob and T. Saeed, "Potential hazards associated with polycyclic aromatic hydrocarbons in weathered crude oil from Kuwait's oil lakes," Journal of Environmental Science and Health. Part A: Environmental Science and Engineering and Toxicology, vol. 29, no. 9, pp. 1777-1787, 1994.

[22] N. Al-Awadhi, R. Al-Daher and M. Balba, "Remediation of oil contaminated sludge's and soil in Kuwait," Paper presented at the 1st International Congress on Petroleum, Contaminated Soils, Sediments and Water, LONDON 2011, pp. 1-24.

[23] N. Al-Awadhi, R. Al-Daher, and Kuwait Institute for Scientific Research (KISR). Remediation and Rehabilitation of Kuwait's Oil Lake Beds, Japan, 2000, Volumes 1-5, Petroleum Energy Center. Amro, M.M., 'Factors affecting chemical remediation of oil contaminated water-wetted soil'. Chemical Engineering \& Technology, vol. 27, no. 8, pp. 890-894, 2004.

[24] N. Ejbarah, R. Al-Jarallah, and D. Al-Dawisan, "House of quality application in soil remediation," Paper presented at the 2nd International Conference on Environmental Science and Technology, IPCBEE, IACSIT Press, Singapore, 2011, pp. 423-427.

[25] H. L. Drake \& M. A. Horn, "As the worm turns: the earthworm gut as a transient habitat for soil microbial biomes," Annu. Rev. Microbiol., vol. 61, pp. 169-189, 2007.

[26] A. Lemtiri, G. Colinet, T. Alabi, D. Cluzeau, L. Zirbes, É. Haubruge, \& F. Francis, "Impacts of earthworms on soil components and dynamics. A review," Biotechnologie, Agronomie, Société et Environnement= Biotechnology, Agronomy, Society and Environment [= BASE], 18, 2014. 